\title{
Validasi Metode Analisis Matriks Patch Domperidon Maleat dengan Perbedaan Polimer Menggunakan Spektorfotometri UV-Vis
}

\section{Validation of Domperidon Maleat Patch Matrix Analysis Method with Polymer Differences Using UV-Vis Spectrophotometry}

\author{
Shesanthi Citrariana ${ }^{1,2 *}$, Oktavia Indrati ${ }^{1}$, Puspa Dwi Pratiwi ${ }^{1,3}$, Ita Nurma Sari ${ }^{1}$, Ari Wibowo ${ }^{1}$ \\ ${ }^{1}$ Pharmacy, Faculty of Mathematics and Natural Sciences, Islamic University of Indonesia, Yogyakarta, Indonesia \\ ${ }^{2}$ Pharmacy, Faculty of Health Sciences, Muhammadiyah University of Palangkaraya, Palangkaraya, Indonesia \\ ${ }^{3}$ Pharmacy, Faculty of Health and Pharmacy, Adiwangsa University of Jambi, Jambi, Indonesia \\ *E-mail: shesanthi.citrariana@umpalangkaraya.ac.id
}

Received: 20 Mei 2021; Accepted: 25 Desember 2021; Published: 31 Desember 2021

\begin{abstract}
Abstrak
Spektrofotometri UV-Vis merupakan metode analisis yang dapat digunakan untuk menetapkan kadar domperidon maleat dalam patch transdermal dengan polimer berbeda. Metode analisis perlu divalidasi untuk membuktikan bahwa metode memberikan hasil pengukuran yang sesuai dengan peruntukannya. Tujuan penelitian ini untuk membuktikan metode spektrofotometri UV-Vis dalam analisa kadar yang digunakan dapat memberikan selektifitas, linieritas, ketelitian, dan ketepatan yang memenuhi persyaratan. Linearitas diketahui dengan menghitung nilai r pada kurva hubungan antara kadar dan absorbansi. Ketelitian diperoleh berdasarkan nilai RSD. Ketepatan dihitung berdasarkan nilai recovery. Selektifitas dengan menghitung rasio absorbansi pada panjang gelombang yang berbeda. Hasil penelitian menunjukkan bahwa metode memenuhi persyaratan yaitu dengan nilai $\mathrm{r}=0,999$; RSD hasil presisi pada kadar 10 ppm diperoleh RSD 0,236\%. Nilai akurasi $80 \%, 100 \%$, dan $120 \%$ pada matriks patch transdermal domperidon maleat dengan polimer PVA dan PVP berturut-turut memiliki nilai \% recovery rata-rata sebesar 99,50\%, 101,15\%, dan 99,13\%. Pada matriks patch transdermal domperidon maleat dengan polimer HPMC dan Na-CMC berturut-turut memiliki nilai \% recovery rata-rata sebesar 100,91\%, 100,31\%, dan 100,67\%. Pada matriks patch transdermal domperidon dengan polimer HPMC dan EC berturut-turut memiliki nilai \% recovery rata-rata sebesar 98,00\%, 98,00\%, dan 99,00\%. Hasil konfirmasi identitas pada matriks patch transdermal domperidon dengan polimer PVA dan PVP, HPMC dan Na-CMC, serta HPMC dan EC berturut-turut memiliki nilai rasio mendekati larutan baku dengan nilai rata-rata sebesar 0,800;0,806; dan 0,808. Dapat disimpulkan bahwa metode analisis kadar domperidone maleat dalam matriks patch transdermal telah memenuhi syarat validitas yang baik.
\end{abstract}

Kata Kunci: domperidon maleat, spektrofotometri UV-Vis, validasi

\begin{abstract}
$U V$-Vis spectrophotometry is an analytical method that can be used to determine the levels of domperidon maleate contained in transdermal patches with different polymers. The analysis method needs to be validated to prove that it can provide measurement results that match its designation. The purpose of this study is to prove that $u v$-vis spectrophotometry methods can provide the specificity, linearity, thoroughness, and precision that meet the requirements. In this study, linearity was known by calculating the $r$ value on the curve of the relationship between levels and absorbance. Precision is obtained based on rsd value. Accuracy is calculated based on the return value. Selectivity is known by means of identity confirmation that calculates the absorbance ratio at different wavelengths. The results showed that the method meets the requirements with a value of $r=0.999$; RSD precision results at a level of 10 ppm obtained RSD $0.236 \%$. The accuracy values of $80 \%, 100 \%$, and $120 \%$ in the matrix of transdermal domperidon maleate patches with PVA and PVP polymers respectively recovery was $99.50 \%, 101.15 \%$, and $99.13 \%$.. In the matrix of transdermal patches domperidon maleate with polymers HPMC and Na-CMC respectively recovery was $100.91 \%$, $100.31 \%$, and $100.67 \%$. In the matrix of transdermal domperidon patches with HPMC and EC polymers respectively recovery was $98.00 \%, 98.00 \%$, and $99.00 \%$. The identity confirmation results on the transdermal domperidon patch matrix with PVA and PVP polymers, HPMC and Na-CMC, as well as HPMC and EC respectively have ratio value close to the standard solution with an average value of 0.800; 0,806; and 0.808. It can be concluded that the method of analyzing the levels of domperidone maleate in matrix of transdermal patches has qualified for good validity.
\end{abstract}

Keywords: domperidon maleate, UV-Vis spectrophotometry, validation 


\section{PENDAHULUAN}

Domperidon maleat (Gambar 1) merupakan antiemetik yang memfasilitasi pengosongan lambung dan mengurangi waktu transit di usus halus dengan meningkatkan gerakan peristaltik lambung dan menurunkan tekanan sfingter esofagus sehingga menghambat refluks makanan naik dan mencegah terjadinya mual dan muntah (Javali et al., 2017).
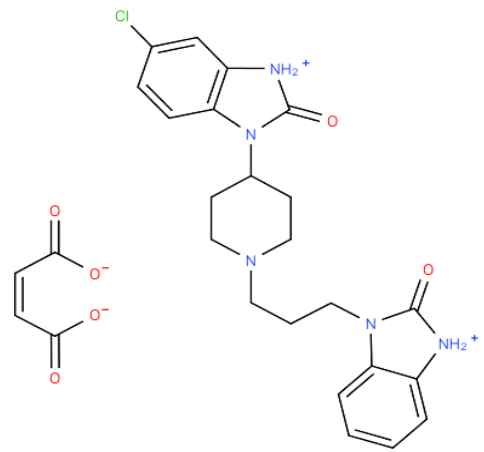

Gambar 1. Struktur domperidone maleat

Tujuan penelitian ini adalah untuk melakukan validasi metode analisis domperidon maleat pada sediaan patch transdermal menggunakan spektofotometer UV. Validasi metode yang digunakan pada penelitian ini dilakukan mengikuti pedoman ICH dan USP (U.S. Pharmacopoeia National Formulary, 2014; ICH Q2A, 2005; ICH Q2B, 2005; Tietje and Brouder, 2010). Validasi metoda analisis domperidone maleat ini merupakan tindakan penilaian terhadap parameter tertentu, berdasarkan percobaan laboratorium, untuk menetapkan bahwa berdasarkan parameter tersebut metode yang akan digunakan dalam kontrol kualitas sediaan ini memenuhi persyaratan (Devi et al., 2012; Harmita, 2004)

\section{METODE PENELITIAN}

\section{Bahan dan Alat}

Domperidon maleat merupakan pemberian dari PT. Zenith Pharmaceutical. Patch transdermal diformulasikan dengan PVP : PVA, EC : HPMC, dan Na-CMC : HPMC. Bahan lain yang diperlukan dalam penelitian diperoleh dari Brataco. Alat yang digunakan dalam penelitian ini adalah spektrofotometer UV 2801 (Horiba), ultrasonic, alat gelas (Pyrex), $\mathrm{pH}$ meter (Horiba).

\section{Skrining Panjang Gelombang}

Domperidon maleat sebanyak $12,73 \mathrm{mg}$ dilarutkan dalam $100 \mathrm{ml}$ buffer fosfat. Larutan diambil $1 \mathrm{ml}$ dilarutkan dalam $10 \mathrm{ml}$ buffer fosfat, dan dilakukan skrining $\lambda$ 200-400nm (Swathi et al., 2019)

\section{Pembuatan Kurva Baku}

Larutan stok domperidon maleat dibuat kadar $127,3 \mathrm{ppm}$. Sebanyak $12,73 \mathrm{mg}$ serbuk domperidon maleat dilarutkan dengan $100 \mathrm{ml}$ buffer fosfat $\mathrm{pH}$ 6,8. Larutan stok diambil 0,8 $\mathrm{ml} ; 1 \mathrm{ml} ; 1,2 \mathrm{ml} ; 1,4 \mathrm{ml} ; 1,6 \mathrm{ml}$; dan $1,8 \mathrm{ml}$ dan diencerkan sampai dengan $10 \mathrm{ml}$ menggunakan buffer fosfat $\mathrm{pH}$ 6,8, hingga diperoleh seri kadar 10,18 ppm; 12,73 ppm; 15,27 ppm; 17,82 ppm; 20,36 ppm; dan 22,91 ppm. Larutan dibaca pada $\lambda \max 283,5 \mathrm{~nm}$ (Karanam et al., 2016).

\section{Linieritas}

Linieritas diukur menggunakan data analisis dari larutan baku pada spektrofotometer yang kemudian diproses dengan metode kuadrat kecil untuk menentukan slope, intersept, dan koefisien korelasinya (Alarfaj et al., 2013; Tietje and Brouder, 2010)

\section{Presisi}

Ditentukan dengan melakukan replikasi sebanyak 6 kali pembacaan pada spektrofotometer terhadap larutan baku domperidon maleat 12,73 ppm (Astuti et al., 2017; Tietje and Brouder, 2010).

\section{Akurasi}

Dibuat matriks patch placebo yang dispike dengan domperidon maleat dengan kadar 80, 100 , dan $120 \%$ dari target konsentrasi obat yang akan dianalisis kemudian ditambahkan $10 \mathrm{ml}$ aquadest dan di oven selama 24 jam. Matriks patch yang telah jadi dimasukkan ke dalam labu ukur $50 \mathrm{ml}$, dilarutkan matriks patch dengan $3 \mathrm{ml}$ DMSO kemudian ditambahkan buffer fosfat $\mathrm{pH}$ 6,8 hingga tanda batas. Larutan diultrasonifikasi selama 30 menit, disaring menggunakan prefilter dan diambil $0,5 \mathrm{ml}$ kemudian dilakukan 
penambahan kembali buffer fosfat hingga 10 $\mathrm{ml}$ dan dilakukan pembacaan pada spektrofotometer sebanyak 3 kali replikasi dan dihitung $\%$ recovery yang didapatkan (Astuti et al., 2017; Tietje and Brouder, 2010).

\section{Batas Deteksi (LOD) dan Batas Kuantitasi (LOQ)}

Batas deteksi dan kuantitasi dapat dihitung secara statistik melalui garis regresi linier dari kurva kalibrasi. Nilai pengukuran akan sama dengan nilai $\mathrm{b}$ pada persamaan garis linier $\mathrm{y}=$ $\mathrm{a}+\mathrm{bx}$, sedangkan simpangan baku blanko sama dengan simpangan baku residual (Sy/x)

$$
\begin{aligned}
& \text { LOD }=\frac{3 \times s y / x}{s l} \\
& \text { LOQ }=\frac{10 x s y / x}{s l}
\end{aligned}
$$

Keterangan:

Sy/x = simpangan baku respon analitik dari blangko

$\mathrm{Sl}=$ arah garis linear (kepekaan arah) dari kurva antara respon terhadap konsentrasi = slope (b pada persamaan garis $y=a+b x$ )

\section{Uji Konfirmasi Identitas}

Uji konfirmasi identitas larutan aku dilakukan dengan menimbang domperidon maleat 12,73 $\mathrm{mg} \approx$ domperidon $10 \mathrm{mg}$ dilarutkan dengan $200 \mathrm{ml}$ buffer fosfat $\mathrm{pH}$ 6,8. Larutan stok diambil berturut-turut 0,$4 ; 0,5 ; 0,6 ; 0,7 ; 0,8$; dan $0,9 \mathrm{ml}$ dan diencerkan dengan $10 \mathrm{ml}$ buffer fosfat $\mathrm{pH}$ 6,8 sehingga diperoleh larutan baku seri kadar 8, 10, 12, 14, 16, 18 ppm. larutan baku dianalisis pada panjang gelombang $280 \mathrm{~nm}$ dan 283,5 $\mathrm{nm}$ kemudian dihitung rasio absorbansi yang diperoleh (Tietje and Brouder, 2010).

Uji konfirmasi identitas sampel dilakukan dengan mengambil 1 matriks patch secara acak, dilarutkan sampai dengan $100 \mathrm{ml}$ buffer fosfat $\mathrm{pH} 6,8$. Larutan diambil 0,$8 ; 1 ; 1,2 ; 1,4$; 1,6; dan 1,8 $\mathrm{ml}$ dan diencerkan dengan $10 \mathrm{ml}$ buffer fosfat $\mathrm{pH}$ 6,8 hingga diperoleh seri kadar kadar 8, 10, 12, 14, 16, 18 ppm. Larutan sampel dianalisis pada panjang gelombang $280 \mathrm{~nm}$ dan 283,5 nm kemudian dihitung rasio absorbansi yang diperoleh (Tietje and Brouder, 2010)

\section{HASIL DAN PEMBAHASAN}

Skrining Panjang Gelombang

Hasil skrining panjang gelombang memperlihatkan bahwa domperidon maleat

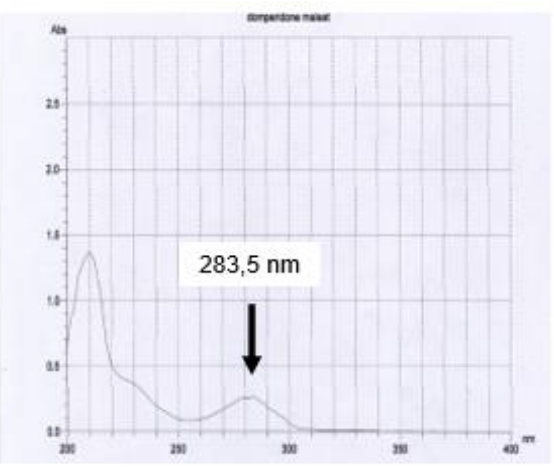

Gambar 2. Panjang gelombang
maksimal domperidon maleat

memiliki panjang gelombang maksimum yang berada pada 283,5 nm (Gambar 2).

\section{Linieritas}

Hasil uji linieritas menunjukan bahwa nilai koefisien kolerasi (r) yang diperoleh telah sesuai dengan parameter nilai $r$ yang baik.

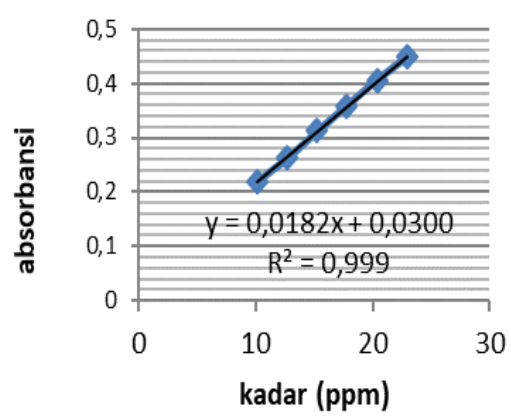

Gambar 3. Grafik linieritas kadar versus absorbansi pembacaan domperidone maleat

Nilai $r$ yang diperoleh pada penelitian ini adalah 0,999 (Wisudyaningsih, 2012). Nilai koefisien korelasi menunjukkan tingkat linearitas hubungan antara kadar analit dan absorbansi. Persamaan yang menyatakan hubungan antara kadar analit persamaan yang menyatakan hubungan antara kadar analit 
Tabel 1. Hasil Pengujian Presisi penetapan kadar domperidone maleat

\begin{tabular}{cccc} 
Replikasi & $\begin{array}{c}\text { Kadar } \\
(\mathbf{p p m})\end{array}$ & \\
\cline { 1 - 2 } 1 & 12,75 & & Rata-rata \\
2 & 12,75 & & $($ ppm $) \pm$ SD \\
3 & 12,80 & & $12,77 \pm 0,03$ \\
& &
\end{tabular}

(ppm) dengan absorbansi dapat dilihat pada (Gambar 3). Nilai $r=0,999$ menunjukkan persamaan kurva baku linear (Dep Kes RI, 2020). al., 2017). Hasil presisi dapat dilihat pada Tabel 1.

\section{Akurasi}

Akurasi dihitung sebagai nilai perolehan kembali atau recovery. Nilai \% recovery berada pada rentang antara $98-102 \%$. Hasil akurasi yang telah dilakukan pada penelitian memperlihatkan kesesuaian dengan rentang recovery yang dipersyaratkan dan nilai RSD yang diperoleh $<2 \%$, sehingga pengukuran dikatakan baik (Nunes et al., 2015). Hasil pengujian akurasi dapat dilihat pada Tabel 2. Batas Deteksi (LOD) dan Batas Kuantitasi (LOQ)

Sensitivitas pengukuran dijelaskan oleh LOD

Tabel 2. Hasil Pengujian Akurasi penetapan domperidone maleat

\begin{tabular}{ccccc}
\hline \multirow{2}{*}{ Akurasi } & $\begin{array}{c}\text { Polimer Pada Matriks } \\
\text { Patch Transdermal }\end{array}$ & $\begin{array}{c}\text { Rata-Rata } \\
\text { Recovery \% }\end{array}$ & SD & RSD (\%) \\
\hline \multirow{2}{*}{$80 \%$} & PVP dan PVA & 99,50 & 0,82 & 0,83 \\
& HPMC dan Na- CMC & 98,00 & 0,48 & 0,48 \\
\multirow{2}{*}{$100 \%$} & HPMC dan EC & 102,51 & 0,54 & 0,53 \\
& PVP dan PVA & 101,15 & 0,50 & 0,49 \\
& HPMC dan Na- CMC & 100,31 & 0,49 & 0,25 \\
$120 \%$ & HPMC dan EC & 98,00 & 0,43 & 0,44 \\
& PVP dan PVA & 99,13 & 0,21 & 0,21 \\
& HPMC dan Na- CMC & 99,00 & 0,61 & 0,61 \\
& HPMC dan EC & 102,03 & 0,42 & 0,41 \\
\hline
\end{tabular}

\section{Presisi}

Ukuran keterulangan atau presisi biasanya dinyatakan dalam simpangan baku relatif (RSD). Metode analisa yang diteliti akan menghasilkan hasil pengukuran yang sama dan LOQ. LOD dalam penelitian ini, yaitu konsentrasi domperidon maleat terendah dapat dideteksi dengan metode tetapi tidak diperlukan untuk analisis adalah 0,651 ppm. Sedangkan LOQ, yaitu konsentrasi minimum

Tabel 3. Perhitungan Simpangan Baku Respon Analitik dari Blanko

\begin{tabular}{|c|c|c|c|c|c|c|c|}
\hline Konsentrasi (ppm) & Absorbansi (y) & yi & $y-\mathbf{y i}$ & $(y-y i) \wedge 2$ & $\mathbf{S}(\mathbf{y} / \mathbf{x})$ & LOD (ppm) & LOQ (ppm) \\
\hline 10,18 & 0,219 & 0,215 & 0,0037 & $1,386 \mathrm{E}-05$ & \multirow{7}{*}{0,00395} & \multirow{7}{*}{0,651} & \multirow{7}{*}{2,171} \\
\hline 12,73 & 0,263 & 0,261 & 0,0013 & $1,726 \mathrm{E}-06$ & & & \\
\hline 15,27 & 0,312 & 0,307 & 0,0040 & $1,669 \mathrm{E}-05$ & & & \\
\hline 17,82 & 0,359 & 0,354 & 0,0046 & $2,186 \mathrm{E}-05$ & & & \\
\hline 20,36 & 0,405 & 0,400 & 0,0044 & $1,978 \mathrm{E}-05$ & & & \\
\hline 22,91 & 0,449 & 0,446 & 0,0020 & $4,153 \mathrm{E}-06$ & & & \\
\hline \multicolumn{4}{|c|}{ Jumlah } & 7,809E-05 & & & \\
\hline
\end{tabular}

pada kondisi percobaan yang sama. Hasil presisi memiliki nilai RSD <2\% yaitu $0,236 \%$, sehingga pengukuran dikatakan baik (Hong et domperidon maleat dalam matriks patch transdermal yang dapat diukur secara akurat adalah 2,171 ppm. Hasil ini menunjukkan 
bahwa sensitivitas metode yang diusulkan cukup untuk pengukuran kelarutan analit dalam bahan patch transdermal (Astuti et al., 2017). Hasil perhitungan LOD dan LOQ dapat dlihat pada Tabel 3.

\section{Konfirmasi Identitas}

Pengujian konfirmasi dilakukan pada semua matrik patch yang diformulasikan dengan polimer berbeda. Selektivitas atau spesifisitas merupakan konfirmasi identitas dari suatu metode yang digunakan untuk membedakan
Singhvi, 2015). Hasil pengujian konfirmasi identitas dapat dilihat pada Tabel 4, Tabel 5, dan Tabel 6.

Konfirmasi identitas dilakukan dengan cara menentukan rasio absorbansi sampel pada panjang gelombang berbeda namun berdekatan yang nantinya dibandingkan dengan rasio absorbansi larutan baku. Apabila rasio absorbansi sampel dengan larutan baku mendekati, maka dapat dinyatakan bahwa metode yang dilakukan dapat dengan spesifik

Tabel 4. Konfirmasi identitas matriks patch transdermal menggunakan PVA dan PVP

\begin{tabular}{ccccccc}
\hline \multirow{2}{*}{ Konsentrasi } & \multicolumn{2}{c}{ Absorbansi } & \multirow{2}{*}{ Rasio } & Rata-rata & SD & RSD (\%) \\
\cline { 2 - 3 } & $\mathbf{2 8 0} \mathbf{~ n m}$ & $\mathbf{2 8 3 , 5} \mathbf{~ n m}$ & & 0,79 & & \\
$10,18 \mathrm{ppm}$ & 0,174 & 0,221 & 0,262 & 0,81 & & \\
$12,73 \mathrm{ppm}$ & 0,212 & 0,318 & 0,79 & & \\
$15,27 \mathrm{ppm}$ & 0,251 & 0,370 & 0,79 & 0,800 & 0,011 & 1,37 \\
$17,82 \mathrm{ppm}$ & 0,289 & 0,405 & 0,81 & & & \\
$20,36 \mathrm{ppm}$ & 0,326 & 0,455 & 0,79 & & \\
$22,91 \mathrm{ppm}$ & 0,360 & & & & & \\
\hline
\end{tabular}

Tabel 5. Konfirmasi identitas matriks patch transdermal menggunakan HPMC dan Na-CMC

\begin{tabular}{ccccccc}
\hline \multirow{2}{*}{ Konsentrasi } & \multicolumn{2}{c}{ Absorbansi } & \multirow{2}{*}{ Rasio } & Rata-rata & SD & RSD $(\%)$ \\
\cline { 2 - 3 } & $280 \mathrm{~nm}$ & $283,5 \mathrm{~nm}$ & & 0,79 & & \\
$10,18 \mathrm{ppm}$ & 0,175 & 0,22 & & 0,81 & & \\
$12,73 \mathrm{ppm}$ & 0,217 & 0,266 & & 0,81 & & \\
$15,27 \mathrm{ppm}$ & 0,249 & 0,313 & 0,79 & 0,806 & 0,0089 & \\
$17,82 \mathrm{ppm}$ & 0,291 & 0,359 & 0,81 & & \\
$20,36 \mathrm{ppm}$ & 0,328 & 0,406 & 0,81 & & \\
$22,91 \mathrm{ppm}$ & 0,367 & 0,451 & 0,81 & & \\
\hline
\end{tabular}

Tabel 6. Konfirmasi identitas matriks patch transdermal menggunakan HPMC dan EC

\begin{tabular}{ccccccc}
\hline \multirow{2}{*}{ Konsentrasi } & \multicolumn{2}{c}{ Absorbansi } & \multirow{2}{*}{ Rasio } & Rata-rata & SD & RSD (\%) \\
\cline { 2 - 3 } & $280 \mathrm{~nm}$ & $283,5 \mathrm{~nm}$ & & & & \\
\hline $10,18 \mathrm{ppm}$ & 0,172 & 0,213 & & 0,81 & & \\
$12,73 \mathrm{ppm}$ & 0,212 & 0,263 & & 0,81 & & \\
$15,27 \mathrm{ppm}$ & 0,247 & 0,301 & 0,82 & & \\
$17,82 \mathrm{ppm}$ & 0,287 & 0,357 & 0,80 & 0,808 & 0,008 & \\
$20,36 \mathrm{ppm}$ & 0,329 & 0,404 & 0,81 & & & \\
$22,91 \mathrm{ppm}$ & 0,348 & 0,436 & 0,79 & & & \\
\hline
\end{tabular}

antara analit dan gangguan pengotor. Selektivitas dan spesifisitas sangat penting dalam analis. Metode yang selektif dan sensitif memberikan tanggapan pada sejumlah komponen yang dapat atau tidak dapat dibedakan satu sama lainnya (Garg and terhadap domperidon.

Kedekatan nilai rasio antara satu konsentrasi dengan konsentrasi lain dapat dilihat dari nilai RSD. Nilai RSD < $2 \%$ menunjukan bahwa rasio yang diperoleh menunjukan kedekatan dan pengujian dapat dikatakan baik. Hasil 
konfirmasi identitas pada matriks patch transdermal domperidon dengan polimer PVA dan PVP memiliki nilai rasio rata-rata sebesar 0,800 Hasil konfirmasi identitas pada matriks patch transdermal domperidon dengan polimer HPMC dan Na-CMC memiliki nilai rasio rata-rata sebesar 0,806. Hasil konfirmasi identitas pada matriks patch transdermal domperidon dengan polimer HPMC dan EC memiliki nilai rasio rata-rata sebesar 0,808 . Sedangkan hasil konfirmasi identitas pada larutan baku memiliki nilai rasio sebesar 0,804 . Hal ini menunjukkan kedekatan rasio pengukuran absorbansi sampel dan larutan baku.

\section{KESIMPULAN}

Metode yang digunakan sudah linier dengan nilai $\mathrm{r}=0,999$; memiliki presisi dengan nilai RSD < 2\%; memiliki akurasi dengan rentang $98-102 \%$ dan nilai RSD < 2\%; hasil konfirmasi identitas memiliki rasio rata-rata pada polimer PVA dan PVP sebesar 0,800, polimer HPMC dan Na-CMC sebesar 0,806, HPMC dan EC sebesar 0,808, larutan baku sebesar 0,804 .

\section{Daftar Pustaka}

Alarfaj N.A., Mostafa A.A. and Al-Ghamdi Z.A., 2013, Spectrophotometric determination of domperidone in its pharmaceutical formulation through charge transfer complexation reactions, Asian Journal of Chemistry, 25 (13), 7377-7380.

Astuti I.Y., Martien R. and Nugroho A.., 2017, Validasi Metode Spektrofotometri Uv-Vis Untuk Studi Kelarutan Pentagamavunon-0 Di dalam Pembawa Self-Nanoemulsifying Drug Delivery System, Pharmacy, 14, 127-136.

Dep Kes RI, 2020, Farmakope Indonesia edisi VI, Kementrian Kesehatan republik Indonesia, Jakarta.

Devi O.Z., Basavaiah K. and Vinay K.B., 2012, Simple, sensitive and selective spectrophotometric methods for the determination of atenolol in pharmaceuticals through charge transfer complex formation reaction, Turk J. Pharm., 9 (1), 27-40.

Garg R.K. and Singhvi I., 2015, UV Spectrophotometric Method Development and Validation for Quantitative Estimation of Nizatidin, Journal of Innovations in Pharmaceuticals and Biological Sciences, 2 (3), 333-336.

Harmita, 2004, Petunjuk Pelaksanaan Validasi Metode Dan Cara Perhitungannya, , I (3), $117-$ 135.

Hong L., Han D., Li M.-X., Zhang P. and Liu C.-G., 2017, Development and validation of an ultraviolet-visible spectrophotometric method for determination of phenylethyl resorcinol in new topical nanoemulsions, Int. J. Cosmet. Sci, 39, 337-343.

ICH Q2A, 2005, Validation of Analytical Procedures: Definitions and Terminology, Geneva, 1995, in 2005 incorporated in Q2(R1).

ICH Q2B, 2005, Validation of Analytical Procedures: Methodology, adopted in 1996, Geneva $Q 2 B$. in 2005 incorporated in Q2(R1),

Javali B., Sravanthi B., Mohan Rao B., Gopi K., Vamsi K., Lakshmana Rao A. and Prasanthi T., 2017, Development and Validation of UV Spectrophotom- etric Method for Simultaneous Estimation of Omeprazole and Domperidone in Capsule Dosage forms, Global Journal of Pharmacy \& Pharmaceutical Sciences, 1 (2), 1-4.

Karanam S.K., Alekhacharan, Soudamini and Madem V., 2016, Method Development and Validation for the Estimation of Domperidone Maleate in Pharmaceutical Dosage Form 
by UV- Spectrophotometry, Int. J. Chem. Pharm. Anal, 3, 1-9.

Nunes P.S., Jesus D.C., Bezerra M.S., Souza J.C.C., Silva F.A., Serafini M.R., Lima B.S., Shanmugam S., Albuquerque Junior R.L.C. and Araújo A.A. de S., 2015, Validation of a UV-VIS Spectrophotometric method for the determination of usnic acid /collagen-based membranes, Scientia Plena, 11 (9)

Swathi B., Subramanyam B., Dharmateja B., Babu M.H. and Kiran D., 2019, Development And Validation Of New Analytical Method For The Simultaneouss Estimation Of Pantoprazole And Domperidone By Uv- Spectrophotometry, Indo Am. J. Pharm. Res, 9 (05), 1993-2000.

Tietje C. and Brouder A. (Eds. ., 2010, International Conference on Harmonisation of Technical Requirements for Registration of Pharmaceuticals for Human Use, in: Handbook of Transnational Economic Governance Regimes, Brill Nijhoff.

U.S. Pharmacopoeia National Formulary, 2014, The Unites States Pharmacopoeial Convention, Rockville, MD, USA.

Wisudyaningsih B., 2012, Studi Preformulasi : Validasi Metode Spektrofotometri Ofloksasin Dalam Larutan Dapar Fosfat, Stomatognatic- Jurnal Kedokteran Gigi, 9 (2), 77-81. 